\title{
BERN RADIOCARBON DATES III
}

\author{
CHR. GFELLER and H. OESCHGER \\ Physikalisches Institut, Universität Bern
}

This list covers part of the measurements made at the Radiocarbon Dating Laboratory, Physics Department, University of Bern from summer 1960 until summer 1962. Two low-level counters with incorporated anticoincidence arrangement (Houtermans and Oeschger, 1958) are used for routine $\mathrm{C}^{14}$ measurements.

As modern reference source we have taken the activity of NBS oxalic-acid standard $\times 0.950$. Errors given are the standard deviations derived from the number of counted particles and the statistical errors of background and modern standard. Results are calculated with the half life of 5568 yr. No $\mathrm{C}^{13}$ corrections are made.

Since the beginning of 1962 samples have been converted into methane using the method described by Fairhall et al. (1961).

This work was financed by the Schweizerischer Nationalfonds. The authors wish to thank Trudi Riesen for the reliable and careful preparation of the samples and her assistance in setting up the methane conversion line, H. Loosli for his assistance in the measurement of part of the samples. They also thank Max Welten and H. G. Bandi for their help in selecting and discussing the samples.

\section{SAMPLE DESCRIPTIONS}

\section{B-199. Eggen, Wallis, Switzerland}

$5250 \pm 80$

3300 B.c.

Peat of sedges and Hypnaceae from a bog behind the lateral moraine of the ancient Aletsch Glacier, N of Blatten and Brig-Naters, Wallis $\left(46^{\circ} 22^{\prime} 13^{\prime \prime}\right.$ $\mathrm{N}$ Lat, $7^{\circ} 59^{\prime} 22^{\prime \prime}$ E Long, alt $\left.1650 \mathrm{~m}\right)$. Coll. 1956 by Max Welten and Otto Hegg; subm. by Max Welten, Univ. of Bern. Comment (M.W.) : good supplement to the Eggen series, B-201, B-200, B-198 (Bern II). Series is consistent (Welten, 1958).

\section{B-204. Belalp, Wallis, Switzerland}

$4240 \pm 80$

2290 в.c.

Root-rich peat from a bog deposit near the Aletsch Glacier, $\mathrm{N}$ of BrigNaters, Wallis $\left(46^{\circ} 23^{\prime} 6^{\prime \prime} \mathrm{N}\right.$ Lat, $7^{\circ} 59^{\prime} 2^{\prime \prime}$ E Long, alt $\left.2330 \mathrm{~m}\right)$. Coll. 1956 by Max Welten and Otto Hegg; subm. by Max Welten. Comment (M.W.) : valuable supplement to the Belalp series B-202, B-203, B-205 (Bern II). Series is consistent (Welten, 1958).

\section{B-290. Le Cruilles $\quad 150.3 \mathrm{~cm}$ depth $\quad 4920 \pm 120$ \\ 2970 в.C.}

Sphagnum peat from Les Cruilles, near Le Pont, Vallé de Joux $\left(46^{\circ} 39^{\prime}\right.$ $4 "$ N Lat, $6^{\circ} 18^{\prime} 36^{\prime \prime}$ E Long, alt $1040 \mathrm{~m}$ ) western Jura. Coll. 1958 by Samuel Wegmüller, Univ. of Bern; subm. by Max Welten. Comment (M.W.) : dates 
the beginning of the Picea phase. Part of a consistent series with B-288, B-289. B-290 (Bern II).

Sèche de Gimel series, western Jura, Switzerland

Peat samples from a sphagnum bog at Sèche de Gimel, near Col du Marchairuz, western Jura $\left(46^{\circ} 33^{\prime} 05^{\prime \prime} \mathrm{N}\right.$ Lat, $6^{\circ} 14^{\prime} 00^{\prime \prime}$ E Long, alt $\left.1300 \mathrm{~m}\right)$. Coll. 1958 by Alfred Wasserfallen and Samuel Wegmüller, Univ. of Bern; subm. by Max Welten. Comment (M.W.) : B-295 and B-294 date the Piceaphase in the western Jura, B-293 the beginning of it.

\section{B-295. Sèche de Gimel $97.8 \mathrm{~cm}$ depth}

B-294. Sèche de Gimel $172.2 \mathrm{~cm}$ depth

B-293. Sèche de Gimel $248 \mathrm{~cm}$ depth

$$
\begin{aligned}
1060 & \pm 100 \\
\text { A.D. } 890 & \\
1500 & \pm 100 \\
\text { A.D. } 450 & \\
3070 & \pm 160 \\
1120 & \text { B.c. }
\end{aligned}
$$

\section{Egelsee series, Simmental, Switzerland}

Samples from a bog profile in Simmental near Diemtigen, Bernese Oberland $\left(46^{\circ} 39^{\prime} \mathrm{N}\right.$ Lat, $7^{\circ} 32^{\prime} 35^{\prime \prime}$ E Long, alt $\left.1000 \mathrm{~m}\right)$, (compare B-50 to B-56, Bern I). Coll. 1957 by J. Liechti and Max Welten; subm. by Max Welten. Comment (M.W.) : realiability of $\mathrm{C}^{14}$ dating of peat was to be examined by comparison with wood found at the same depth. B-306 and B-307 are congruent within the limits of error, even if we do not suspect that the twig was younger and sank a little into the peat.
B-306. Egelsee $80 \mathrm{~cm}$ depth, sphagnum peat$$
580 \text { в.с. }
$$
$2350 \pm 100$
400 в.C.$$
2530 \pm 100
$$
B-307. Egelsee $80 \mathrm{~cm}$ depth, wood of twig
$3250 \pm 80$
1300 B.c.

\section{B-309. Aare, Aarau, Switzerland}

Trunk of oak from the bed of the river Aare, Áarau $\left(47^{\circ} 24^{\prime} 10^{\prime \prime} \mathrm{N}\right.$ Lat, $8^{\circ}$ 03' 55" E Long). Coll. 1960 by Mr. Blesi, Juracementfabrik Aarau; subm. by W. Schmid, Mus. für Natur- und Heimatkunde, Aarau. Comment (Mr. B) : dates high-water stage during which trunk was floated into the Aare.

\section{B-318. Monbijoubrïcke \\ $>45,000$}

Small pieces of coal found in sandy layers under ground moraine and Würm II gravels at Monbijoubrücke, Bern ( $46^{\circ} 56^{\prime} 26^{\prime \prime} \mathrm{N}$ Lat, $7^{\circ} 26^{\prime} 31^{\prime \prime} \mathrm{E}$ Long), Gerber, 1927. Coll. 1960 and subm. by W. Nabholz. Geol. Inst., Univ. of Bern. Comment (W.N.) : sample establishes the Pre-Würm II age of the sands.

\section{Creux du Croue series, western Jura, Switzerland}

Sphagnum peat from a bog at Creux du Croue, near Le Noirmont, in western Jura $\left(46^{\circ} 29^{\prime} 48^{\prime \prime} \mathrm{N}\right.$ Lat, $6^{\circ} 7^{\prime} 17^{\prime \prime}$ E Long, alt $\left.1360 \mathrm{~m}\right)$. Coll. 1958 by Alfred Wasserfallen and Samuel Wegmüller; subm. by Max Welten. Com- 
ment (M.W.) : B-331 dates the beginning of the Piceae-phase, B-330 the phase of Corylus.
B-331. Creux du Croue $176.4 \mathrm{~cm}$ depth
$4350 \pm 100$
B-330. Creux du Croue $386.2 \mathrm{~cm}$ depth
2400 в.c.
$8430 \pm 120$
6480 в.с.

\section{Axel Heiberg-Island series, NWT, Canda}

Samples from organic and inorganic sediments in front of White Glacier. The profile was opened naturally by the erosion of a glacier-river $\left(79^{\circ} 26^{\prime} \mathrm{N}\right.$ Lat, $90^{\circ} 24^{\prime} \mathrm{W}$ Long). Coll. 1960 by Otto Hegg, Univ. of Bern; subm. by Max Welten. Comment (M.W. and O.H.) : series of deposits was supposed to give dates of advances and retreats of the glaciers connected with upheaval of the area. In the lower part the profile seems to show a normal deposition up to ca. $100 \mathrm{~cm}$ below surface, while the upper one shows an inversion probably caused by redeposition of older materials. Definite evaluation demands further researches on similar places in the area (Hegg, 1961).
B-333. Axel Heiberg 35 cm depth
$4950 \pm 200$

Drepanocladus-peat layers interbedded with thin sand layers.

\section{B-334. Axel Heiberg $80 \mathrm{~cm}$ depth \\ $3070 \pm 120$ \\ 1120 в.с.}

Drepnaocladus peat.
B-311. Axel Heiberg $135 \mathrm{~cm}$ depth
$2900 \pm 120$
950 в.C.

Drepanocladus peat.

\section{B-313. Axel Heiberg $255 \mathrm{~cm}$ depth}

Rhizome peat.

\section{La Tourbière series, Ct. de Vaud, Switzerland}

Gyttja with chalk and clay from a bog at La Tourbière near Coinsins $\left(46^{\circ}\right.$ $25^{\prime} 40^{\prime \prime} \mathrm{N}$ Lat, $6^{\circ} 13^{\prime} 50^{\prime \prime}$ E Long, alt $\left.480 \mathrm{~m}\right)$. Coll. 1961 by Samuel Wegmüller; subm. by Max Welten. Comment (M.W.) : samples date the phase of Betula-Pinus (Alleröd) in the western part of Switzerland. The slight inconsistency of the series falls within the limits of error, but makes far-reaching conclusions unwarranted.
B-336. La Tourbière $507 \mathrm{~cm}$ depth
$10,950 \pm 200$ 9000 в.с.
B-337. La Tourbière
$511 \mathrm{~cm}$ depth
B-338. La Tourbière $514.5 \mathrm{~cm}$ depth
$11,530 \pm 200$
9580 в.с.
B-339. La Tourbière $518 \mathrm{~cm}$ depth
$11,200 \pm 200$
9250 в.C.
$11,750 \pm 200$
9800 в.с.




\section{B-355. Davos-Platz}

Larch wood from ca. $2 \mathrm{~m}$ depth in soft soil and peat at Davos-Platz, Canton Graubünden (46 49 $\mathrm{N}$ Lat, $9^{\circ} 50^{\prime}$ E Long). Coll. 1961 by R. Haefeli and H. R. in der Gand; subm. by Krähenbühl and Bühler, architects, Davos. Comment (R.H.) : either the yearly sedimentation of coarse- and fine-grained soil (deposited by the river Land-Wasser) was extremely small, or erosion, alternating with deposition, has removed much of the section (Lütschg, 1944).

\section{B-361. Sangenholz, Egnach, Thurgau}

Charcoal from a cultivated field at Sangenholz, Egnach, Canton Thurgau ( $47^{\circ} 32^{\prime} 06^{\prime \prime} \mathrm{N}$ Lat, $9^{\circ} 23^{\prime} 48^{\prime \prime} \mathrm{E}$ Long). Coll. by M. Trächsel; subm. by W. U. Guyan, Mus. zu Allerheiligen, Schaffhausen.

\section{Aletschgletscher series, Switzerland}

Two larch trunks from moraine on right side of Grosser Aletschgletscher, $30 \mathrm{~m}$ above present ice level, Zenbächen $\left(46^{\circ} 25^{\prime} \mathrm{N}\right.$ Lat, $8^{\circ} 02^{\prime} 5^{\prime \prime} \mathrm{E}$ Long, alt $1850 \mathrm{~m}$ ). Trees were lying parallel, a few meters apart, the smaller ends pointing S. Coll. 1961 by R. Haefely and Forstmeister Ritz; subm. by R. Haefely, Susenbergstr. 193, Zürich. Comment (R.H.) : it is possible but not certain that the trees were overridden by the advancing glacier. Transport by avalanches is not excluded. There is no doubt that the trees were uncovered by the retreat of the glacier in the early 1900's or late 1800's. Compare B-32 and B-71 (Bern I), wood samples found at the right side of the tongue of the Grosser Aletschgletscher, but at an alt of $1600 \mathrm{~m}$ (Oeschger and Röthlisberger, 1961).

\section{B-362/1. Aletschgletscher III}

\section{B-362/2. Aletschgletscher IV}

\section{B-379. Hof wiesen I, Bargen, Schaffhausen}

$$
\begin{array}{r}
1760 \pm 100 \\
\text { A.D. } 190 \\
1860 \pm 100 \\
\text { A.D. } 90 \\
1610 \pm 100 \\
\text { A.D. } 340
\end{array}
$$

Sample from charcoal deposit below water-meadow near Hofwiesen, Bargen, Canton Schaffhausen $\left(47^{\circ} 47^{\prime} 48^{\prime \prime}\right.$ N Lat, $8^{\circ} 35^{\prime} 03^{\prime \prime}$ E Long). Coll. 1961 by Margrit Sauter; subm. by W. U. Guyan. Comment (W.G.) : dates an iron furnace.

\section{Goeschenenalp series, Switzerland}

During construction of the earth dam for the Goeschenenalp reservoir, Canton Uri $\left(46^{\circ} 38^{\prime} 51^{\prime \prime} \mathrm{N}\right.$ Lat, $8^{\circ} 29^{\prime} 29^{\prime \prime}$ E Long, alt $1687 \mathrm{~m}$ to $\left.1698.4 \mathrm{~m}\right)$, extensive drilling and excavations were carried out in thick valley fill which contained, at different levels, various organic material from scattered driftwood and roots to peat and remnants of forests. Coll. 1960 by Louis Kläy, Federal Inst. of Technol. Zürich, and Heinrich Zoller, Univ. of Basel; subm. by Sect. of Hydrology and Glaciology, for Hydraulic Research and Soil Mechanics, 
Federal Inst. of Technol., Zürich, and Heinrich Zoller. Comment (Hans Röthlisberger) : B-380 and B-381 date a boulder zone by bracketing it; the boulder zone, av. thickness 8 to $10 \mathrm{~m}$ of considerable lateral extent, imbedded in alluvium, suggests a glacier advance of 2 to $3 \mathrm{~km}$ beyond the 1850 maximum. The boulders may represent a rockslide onto the glacier. B-382 (trunk of Larix) shows that the glacier advanced into a forest. Pollen profiles are under investigation.

\section{B-381. Goeschenenalp la}

\section{B-381/1. Goeschenenalp $1 \mathrm{~b}$}

\section{B-380. Goeschenenalp 2}

\section{B-384. Goeschenenalp 3}

\section{B-382. Goeschenenalp 4}

$$
\begin{gathered}
1400 \pm 80 \\
\text { A.D. } 550 \\
1650 \pm \mathbf{8 0} \\
\text { A.D. } 300 \\
2280 \pm 120 \\
330 \text { B.c. } \\
\mathbf{2 8 4 0} \pm \mathbf{8 0} \\
\mathbf{8 9 0} \text { B.c. } \\
\mathbf{3 3 4 0} \pm \mathbf{1 2 0} \\
1390 \text { в.c. }
\end{gathered}
$$

\section{Tour St. Martin series, Mollondin, Switzerland}

Small bits of burnt wood from Tour St. Martin, Canton Vaud $\left(46^{\circ} 45^{\prime} 3^{\prime \prime}\right.$ $\mathrm{N}$ Lat, $6^{\circ} 45^{\prime} 00^{\prime \prime} \mathrm{E}$ Long). From thick layer of burnt wood mixed with dry sand underneath a cobblestone pavement (empierrement). Coll. 1961 and 1962 and subm. by E. André, Service des Bâtiments de l'Etat, Lausanne. Comment: the two tests show that the pavement belongs to a medieval structure, not to a Roman or even pre-Roman one as had been thought. Gives earliest occupation of hill.

\section{B-392/2. Tour St. Martin}

$$
1190 \pm 100
$$

B-392/4. Tour St. Martin

$$
\text { A.D. } 760
$$

$$
1260 \pm 120
$$

A.D. 690

\section{Vorderrhein series, Ilanz, Graubiinden, Switzerland}

Oak trunks found in river clay and gravel at the bank of the Rhein River after high water near Ilanz, Canton Graubünden $\left(46^{\circ} 46^{\prime} 32^{\prime \prime} \mathrm{N}\right.$ Lat, $9^{\circ} 9^{\prime} 48^{\prime \prime}$ E Long). Coll. 1961 by J. Montalta and H. Calortscher, Ilanz; subm. by H. Brunner, Naturh. Mus. Chur, Graubünden. Comment (H.B.) : postglacial landslide of Flims has dammed the Vorderrhein from Ilanz to Truns. The drifted oak wood, imbedded in sedimenting clay and gravel, may possibly date the landslide (Staub, 1938).

\section{B-395a. Vorderrhein}

Sample from big oak trunk below bark.

$$
\begin{aligned}
& 8320 \pm 120 \\
& 6370 \text { в.c. } \\
& 8570 \pm 130 \\
& 6620 \text { в.C. }
\end{aligned}
$$$$
\text { B-395b. Vorderrhein }
$$

Sample from center of same oak trunk (ca. 300 tree rings below bark). 


\section{B-395c. Vorderrhein}

Sample of small oak trunk.

\section{B-397. Speicher, Hohrüti, Switzerland}

$8470+150$

6520 в.c.

$$
1460 \pm 100
$$$$
\text { A.D. } 490
$$

Root and stem, excavated during construction of a building, found interstratified in upper and lower boulder clay, 250 to $280 \mathrm{~cm}$ depth $\left(47^{\circ} 25^{\prime} 01^{\prime \prime}\right.$ N Lat, $7^{\circ} 6^{\prime} 15^{\prime \prime}$ E Long, alt $940 \mathrm{~m}$ ). Coll. 1961 and subm. by Hermann Eugster, collaborator of Swiss Geol. Comm. Comment (H.E.) : root and stem evidently belong to a landslide, not to a Riss-Würm interglacial deposit.

\section{Il Fuorn series, Unterengadin, Switzerland}

Peat of sedges and Hypnaceae mixed with some sand of dolomite rocks from slightly inclined bog, $\mathbb{W}$ of the Ofenpass road near the Hotel of Il Fuorn $\left(46^{\circ} 39^{\prime} 35^{\prime \prime} \mathrm{N}\right.$ Lat, $10^{\circ} 12^{\prime} 12^{\prime \prime}$ E Long, alt $\left.1805 \mathrm{~m}\right)$. Coll. 1958 and subm. by Max Welten. Comment (M.W.) : the three determinations form a consistent series in a profile formerly thought to record influences of a primitive iron industry on vegetation. The dates confirm the pollen diagrams in demonstrating an age much older than Iron Age and a long span of time for the deposition (Welten, 1962).

\section{B-405. II Fuorn $112 \mathrm{~cm}$ depth \\ $4100 \pm 100$ \\ 2150 в.c. \\ B-406. Il Fuorn $168 \mathrm{~cm}$ depth \\ $5410 \pm 100$ \\ B-407. Il Fuorn $226 \mathrm{~cm}$ depth \\ 3460 в.c. \\ $6490 \pm 100$ \\ 4540 в.c.}

\section{Lai Nair series, Unterengadin, Switzerland}

Samples from a little basin on the right bedrock slope under former Inn glacier, filled, successively, with clay and chalk-gyttja in late-glacial time, with gyttja in Boreal and Atlantic times and later with peat of sedges and Hypnaceae. Boring by Hiller sampler, $\mathrm{E}$ of Tarasp near the thermal station of Schuls (46 46 $26^{\prime \prime} \mathrm{N}$ Lat, $10^{\circ} 16^{\prime} 40^{\prime \prime}$ E Long, alt $\left.1546 \mathrm{~m}\right)$. Coll. 1958 and subm. by Max Welten. Comment (M.W.) : a very consistent series dating the best pollen-diagram available in the neighborhood of the climatically continental Swiss National Park. The early invasion of Picea is dated, as well as the renewed dominance of Pinus in more recent times (Welten, 1962).

\section{B-408. Lai Nair $88 \mathrm{~cm}$ depth}

Peat of sedges and Hypnaceae

\section{B-409. Lai Nair $222 \mathrm{~cm}$ depth}

Peat of sedges and Hypnaceae.

\section{B-410. Lai Nair $277 \mathrm{~cm}$ depth}

Peat of sedges and Hypnaceae, with gyttja.

$$
\begin{gathered}
1310 \pm 80 \\
\text { A.D. } 640 \\
1830 \pm 80 \\
\text { A.D. } 120 \\
2730 \pm 130 \\
780 \text { в.c. }
\end{gathered}
$$




\section{B-411. Lai Nair $331 \mathrm{em}$ depth}

$4000 \pm 80$

Gyttja.

\section{B-412. Lai Nair $410.7 \mathrm{em}$ depth}

Chalk-gyttja.

$7160 \pm 110$

5210 в.с.

\section{Juf Plan series, Unterengadin, Switzerland}

Peat of sedges and Hypnaceae from great alpine inundation plain, formed partly by peat, partly by clay and sand. Boring by Hiller sampler, E of the Ofenpass near the Swiss National Park ( $46^{\circ} 37^{\prime} 18^{\prime \prime}, 10^{\circ} 15^{\prime} 20^{\prime \prime}$, alt $\left.2223 \mathrm{~m}\right)$. Coll. 1958 and subm. by Max Welten. Comment (M.W.) : unexpectedly the profile goes back to the early part of the Atlantic period; the pollen diagram is monotonous and confused by much pollen of long-distance transport, and had not been thought to be so old. The rate of growth of this alpine peat seems to have been very low, and there is no indication of truncation or of cessation of growth in recent times (Welten, 1962).

\section{B-413. Juf Plan 30 cm depth}

$$
3520 \pm 120
$$

\section{B-414. Juf Plan $61 \mathrm{~cm}$ depth}

Date lists:

\section{REFERENCES}

Bern I Oeschger, Schwarz and Gfeller, 1959

Bern II Gfeller, Oeschger and Schwarz, 1961

Fairhall, A. W., Schell, W. R., and Takashima, Y., 1961, Apparatus for methane synthesis for radiocarbon dating: Rev. Sci. Instruments, v. 32, no. 3, p. 323.

Gerber, E., 1927, Geologische Karte von Bern und Umgebung: Bern, Kümmerly \& Frey.

Gfeller, Chr., Oeschger, H., and Schwarz, U., 1961, Bern radiocarbon dates II: Radiocarbon, v. 3 , p. $15-25$.

Hegg, O., 1961, Preliminary report on the palynological field work 1960, including two radiocarbon datings: Jacobson-McGill Arctic Research Exped. to Axel Heiberg Island, Preliminary Rept., McGill Univ., Montreal.

Houtermans, F. G., and Oeschger, H., 1958, Proportionalzählrohr zur Messung schwacher Aktivitäten weicher $\beta$-Strahlung: Helv. Phy. Acta, v. 31, p. 117-126.

Luetschg, O., 1944, Zum Wasserhaushalt des Schweizer Hochgebirges: II. Band, Beiträge zur Geologie der Schweiz, Geotechnische Serie--Hydrologie, 4. Lieferung, 1944: Bern, Kümmerly \& Frey.

Oeschger, H., Schwarz, U., and Gfeller, Chr., 1959, Bern radiocarbon dates I: Am. Jour. Sci Radioc. Supp., v. 1, p. 133-143.

Oeschger, H., and Röthlisberger, H., 1961, Datierung eines ehemaligen Standes des Aletschgletschers durch Radioaktivitätsmessungen an Holzproben und Bemerkungen zu Holzfunden an weiteren Gletschern: Zeitschrift Gletscherkunde und Glaziologie, 1961, v. 4 , p. 191-205.

Staub, R., 1938, Neues und altes vom Flimser-Bergsturz: Mittg. Schweiz. Naturf. Ges., p. 60 .

Welten, Max, 1958, Die spätglaziale und postglaziale Vegetationsentwicklung der BernerAlpen und -Voralpen und des Walliser Haupttals: Geobot. Inst. Rübel, Veröffentl., no. 34 , p. $150-158$.

1962, Einige Ergebnisse pollenanalytisch-vegetationsgeschichtlicher Untersuchungen im Unterengadin: Verh. Schweiz. Naturf. Ges., in press. 